\title{
APPLYING THE MOODLE SYSTEM IN TEACHING CONTEMPORARY ART
}

\section{PRIMJENA SUSTAVA MOODLE U POUČAVANJU SUVREMENE UMJETNOSTI}

\author{
Suzana Tomaš, Julija Tomasović, Dubravka Kuščević \\ Faculty of Humanities and Social Sciences, University of Split, Split, Croatia \\ Filozofski fakultet, Sveučilište u Splitu, Split, Hrvatska
}

\section{Abstract}

The development of modern technologies, applying pedagogical principles, has enabled a new educational paradigm of e-learning, which represents quality support to teachers in the transfer of knowledge. This paper presents the possibilities of applying an e-learning system in teaching visual arts, precisely in teaching contemporary art. Well-designed and applied teaching content in an e-learning system enables various scenarios of learning, teaching, and testing the knowledge of contemporary art. Contemporary art thus becomes a communication within which the observer becomes an interpreter of the different levels of meaning of an artwork. This research, designed as an educational experiment, involved 57 students from two primary schools in Split-Dalmatia County. We found differences in the knowledge and preferences of fourth graders regarding contemporary art with respect to teaching methods. The results show increasing student preferences for contemporary art in a group using the Moodle system and in a group of students creating inspired by contemporary artworks. Students expressed satisfaction with learning about contemporary art using Moodle. The difference between the results of the initial and final testing of knowledge showed statistical significance in the groups that had art lessons. Moodle provides opportunities to learn a variety of content, including contemporary art in primary school.
Sažetak

Razvoj suvremenih tehnologija uz primjenu pedagogijskih načela omogućio je novu obrazovnu paradigmu e-učenja što predstavlja kvalitetnu podršku učiteljima u prijenosu znanja. U ovom radu prikazane su mogućnosti primjene sustava e-učenja u nastavi likovne kulture u poučavanju suvremene umjetnosti. Dobro oblikovan i primijenjeni nastavni sadržaj u sustavu e-učenja omogućava različite scenarije učenja, poučavanja i testiranja znanja suvremene umjetnosti. Suvremena umjetnost postaje komunikacija unutar koje promatrač postaje interpretator različitih razina značenja koje posjeduje umjetničko djelo. U istraživanju koje je predstavljalo obrazovni eksperiment sudjelovalo je 57 učenika iz dvije osnovne škole u Splitsko-dalmatinskoj županiji. Utvrdili smo postojanje razlika u znanju i preferencijama učenika četvrtog razreda osnovne škole prema suvremenoj umjetnosti s obzirom na način podučavanja. Rezultati pokazuju da učeničke preferencije suvremene umjetnosti rastu u skupini koja je poučavana preko sustava Moodle i skupini učenika koja je stvarala na tragu suvremene umjetnosti. Učenici su iskazali zadovoljstvo učenjem suvremene umjetnosti na Moodle. Razlika rezultata početnog i završnog testiranja znanja pokazala je statističku značajnost u skupinama koje su se likovno educirale. Moodle pruža mogućnosti učenja različitog sadržaja, između ostalog i suvremene umjetnosti u osnovnoj školi. 


\section{Contemporary art in Visual arts education}

Visual art communication is important in the education of children and the young. From the earliest age, it is necessary to develop students' competences of visual language and visual thinking, which is achieved through successful visual art communication in contact with artworks. Contact with quality artworks enables students to make aesthetic judgments. Since art can have an impact on society, it can be said that education and art are in a mutual dialogue, making it essential to acquaint students with works of contemporary art in order to understand the social context of their time. In other words, Karlavaris states that "Visual arts education must start from social situations and relationships, it must prepare students for life, for society and the time in which they live."/1/

Visual arts education contributes to the development of society respecting social laws, while art, following social changes, is itself subject to change. Art has been introducing new meanings into the field of human culture since the beginning of the twentieth century and is no longer based on the notion of beauty, harmony and artistic skills, but is understood as an idea, a design, a concept. We call current art by the name of contemporary art, art that lasts the moment it is discussed. Thus, contemporary art as a term does not refer to the properties of action, but to current art occurring in the spirit of the times /2/. Contemporary art becomes a communication within which the observer becomes an interpreter of the different levels of meaning of an artwork. This means a contemporary artwork depends on the individual interpretation of the observer. Conceptual art, occurring in the 1960s and 1970s, shifts attention from works, artistic techniques, and art form to the communicative level of visual arts. The term contemporary art refers to those ways of artistic expression that followed after 1960 and which do not use established ways of expression, but seek new ways of expression, often mixing art areas, and instead of established problems with art form introduce content from the immediate environment $/ \mathbf{3} /$.

Actually, contemporary art is aimed towards art democratization seen in liberation from capital and elite circles, in the use of simple means of expression and techniques, presentation on the street or in large areas accessible to all. Thus, the art of modern times integrates spaces in which people move, live, work, reaching the places where all people can meet it and where it can affect a larger number of recipients. Additionally, art becomes an integral part of propaganda, of agitation and as such points to the expansion of the social role of visual arts in everyday life /4/. Thus, art reflects social events in a complex way, but it is also a stimulus for new social changes; art is not intended for a narrow group of people, but for all humans.

Modern society sees rapid changes of life and work of an individual, requiring changes and rapid adaptation to social conditions, therefore it is important to develop competencies that contribute to education and development at the individual and social level /5/. Visual art education in schools is based on visual art ideas and practices active to the 20th century, differing in their art forms from the contemporary art of the 21st century. The art of the past is separate from the student's daily life. Cole points out that by teaching students classical art, art may seem unimportant to the young as they see no connection between art and the things that interest them /6/. The gap between contemporary art and the general public is growing primarily due to the narrow-minded and traditional approach to visual art evaluation. It is necessary to be aware of the different meaning and role of contemporary art in society and school today. "One of the most common reactions to contemporary art is the objection that the art exhibit is flawed, giving a feeling of lack of skills. Contemporary art lives and works in the same world and time as a child, and it speaks in different ways and through different media about the same problems that affect today's children and their loved ones /7/. To accept the language of contemporary art, the student must be given the opportunity to participate in the creation of contemporary art. Nowadays, there is a discrepancy between what is happening in contemporary art and what is taught and introduced in Visual arts education in primary school. When visiting exhibitions of contemporary artworks, students remain 
confused, and most often reject vague and different art /op. cit. 3/. It is necessary to connect contemporary art with Visual arts education in order for students to accept its forms and understand the connection between social events and artistic creation. In the research /op.ct 7/, the authors analyzed the connection between education and contemporary art and concluded that the successful incorporation of contemporary art practice in everyday Visual arts education in Slovenia requires quality teacher education. The research /8/ found that primary and secondary schools in Slovenia do not pay enough attention to the practice of contemporary art in the classroom, and teachers do not sufficiently include the works of contemporary artists in Art education in the classroom. Thus, students do not have enough information about experiencing and understanding contemporary art and have a problem in understanding, reading the content and way of expression in works of contemporary art.

\section{Using Moodle in teaching contemporary art}

Advances in information and communication technology (ICT) have led to new learning and teaching methods based on the use of computers in education /9/. Applying information and communication technology enables quality and simple teacher-student and student-student communication in the educational process. The use of ICT in teaching enables flexibility in the sense of availability of teaching materials $/ \mathbf{1 0} /$. Information and communication technology is an integral part of the education system, whereupon teaching is increasingly student-oriented while student becomes an active participant in the teaching process. This way of teaching enables the collection, storage, transmission, and processing of all types of information. Teaching thus faces numerous new perspectives and opportunities. Also important in education is the Internet, which in its unlimited potential stimulates students' curiosity and desire for knowledge /11/. During primary education, an average student spends less than 5,000 hours reading in the Internet environment and more than 10,000 hours playing video games /12/. Such a student needs to be provided with new methods, techniques, tools as well as a new teacher's approach in the process of learning, teaching and knowledge testing. The development of such a way of teaching enables learning at any time and in any place, while implementing such education takes place in an online environment. The student and the teaching contents, and their interaction, must be at the center of online learning. In this way, the student acquires knowledge that is the education objective. Therefore, the design of teaching in elearning systems should follow the principles of theories of design of teaching content, which is especially important in e-learning systems, where the student and teacher are physically separated. E-learning includes support for a range of different electronic media (Internet, intranet, satellite, audio/videotapes, interactive $\mathrm{TV}$, and CD-ROM) to make learning more flexible /13/. In addition, the development of online learning enables e-learning which is implemented in e-learning systems. The synergy of technology and education forms e-learning, and their connection is strongly supported by those who design teaching content in e-learning systems /14/. Well-designed and applied teaching content in the e-learning system enables different scenarios of learning, teaching and knowledge testing. The aim of this research is to measure students' preferences towards contemporary art, the contents of which are designed and developed in the e-learning system. The elearning system in this paper is the Learning management system (LMS).

Learning management system is a software that enables the application of teaching content and the administration of the learning and teaching process. LMS uses human and technological resources that adequately enhance learning to an environment for the design of teaching content intended for teachers as course leaders. Given that our task in the research was to determine whether the application of e-learning systems can improve the acquisition of knowledge of contemporary art, the learning environment was the Moodle system. Moodle is a learning management system, but it is also perceived as a virtual learning and teaching environment. 
The acronym Moodle means Modular Object-Oriented Dynamic Learning Environment. Modularity means that the system consists of smaller modules, activities that together form a whole just like in any e-learning system. Object-oriented refers to the way of programming, the system is built based on objects, entities with defined roles and described data set. Moodle learning environment is dynamic, and the student actively participates in the learning process. Moodle is an open-source system allowing system users to make changes to applications and adapt them to their own needs $/ \mathbf{1 5} /$. Moodle offers following possibilities: creating a large number of courses using one system, course planning, activity schedule, calendar, user management, management of user roles and user groups in the course, working with existing files and educational content, testing and evaluating users, monitoring user activities, numerous tools for communication and user cooperation, system management-backups, statistics, logs, extensive help system.

Based on the user roles in the Moodle system, the following activities were applied in this research: lesson, test, and communication and collaboration tools. The lesson activity is designed as a set of pages on which the teaching contents are presented in written or graphic form. Links, animations, multimedia, and images are added to the teaching content. The pages are joined not only with the content, but also with the questions through which the student checks what she/he has learned. Since this is programmed learning, students, after answering the question correctly, continue learning; if they make a mistake, they return to the page where the content must be repeated.

This way of learning obliges students to answer the question correctly, as one of the problems of e-learning is motivation drop, which can result in not learning. A test is an activity in the Moodle system that includes settings and a set of questions. The set of questions in the system is added by selecting individual types of questions, thus forming a database of questions from which the questions are joined to the test. The types of questions in the test include three types of question formation: recall, completing, and computing. When doing the test, after each answered question, the student ISSN 1330-0067 receives feedback on the accuracy of the answer. At the end of the quiz, the student receives the overall feedback and the grade obtained based on the given answers. Students do this task activity within the given time limit, and the task can be performed in three ways: by submitting the answers in writing, when the grade is entered into the system; by writing the answers in the system itself, and submitting the answers in the form of a created document that is transferred to the system. After the deadline, the task is evaluated providing feedback on the accuracy of the answers /16/. Asynchronous communication $/ \mathbf{1 7}$ / is an occasional communication between students and teachers scheduled at a specific time. This kind of communication took place in a forum on the Moodle system. In the forum, students answered questions related to the topic of contemporary art. Moodle's constructivist approach allows students to control shared content using a forum, wiki, database, sending messages via chat. It is also possible to give students more control over content by deleting discussions from the forum or editing test questions, therefore the learning environment should be flexible and adaptable, so that it can quickly respond to the needs of its participants.

\section{Research}

\section{The research objective, research object, and re-} search questions

The research object is contemporary art. In our primary schools, children are less familiar with contemporary art, therefore we wanted to put it at the center of research on children's art preferences. The research objective is to measure the preferences of fourth graders towards contemporary art by teaching in the traditional way and in the e-learning system. Based on the set goal of the research, we formulated the following research questions:

1. Is there a connection between the way of teaching and the preferences of fourth graders towards contemporary art?

2. Are fourth graders satisfied with learning using the Moodle system?

3. Is there a difference in knowledge about contemporary art between students of

Coden: IORME7 
group A (experimental group - students creating on the trail of contemporary art) and of group B (experimental group - students using Moodle) in terms of the difference between initial and final measurement in objective-type tasks (ZOT)?

\section{Sample of respondents, research instrument, and data processing procedure}

The locations of the two-month research were two primary schools in the Split-Dalmatia County. The research sample includes three fourth grade classes of primary school with a total of 57 students $(\mathrm{N}=57)$ (Table 1$)$.

Table 1. Number of students by the group

\begin{tabular}{|l|l|l|l|}
\hline Group & $\begin{array}{l}\text { No. of stu- } \\
\text { dents }\end{array}$ & No. of girls & No. of boys \\
\hline $\begin{array}{l}\text { Group A (experimental - students creat- } \\
\text { ing on the trail of contemporary art) }\end{array}$ & 19 & 8 & 11 \\
\hline $\begin{array}{l}\text { Group B } \\
\text { (experimental - Moodle) }\end{array}$ & 19 & 8 & 11 \\
\hline Group C (control) & 19 & 8 & 11 \\
\hline Total & 57 & 24 & 33 \\
\hline
\end{tabular}

In the first experimental group (A), students were taught about contemporary art, followed by creating their artworks showing contemporary art expression.
In the second experimental group (B), students were taught in the Moodle system about contemporary art, collaborated, and communicated on the forum (Figure 1).

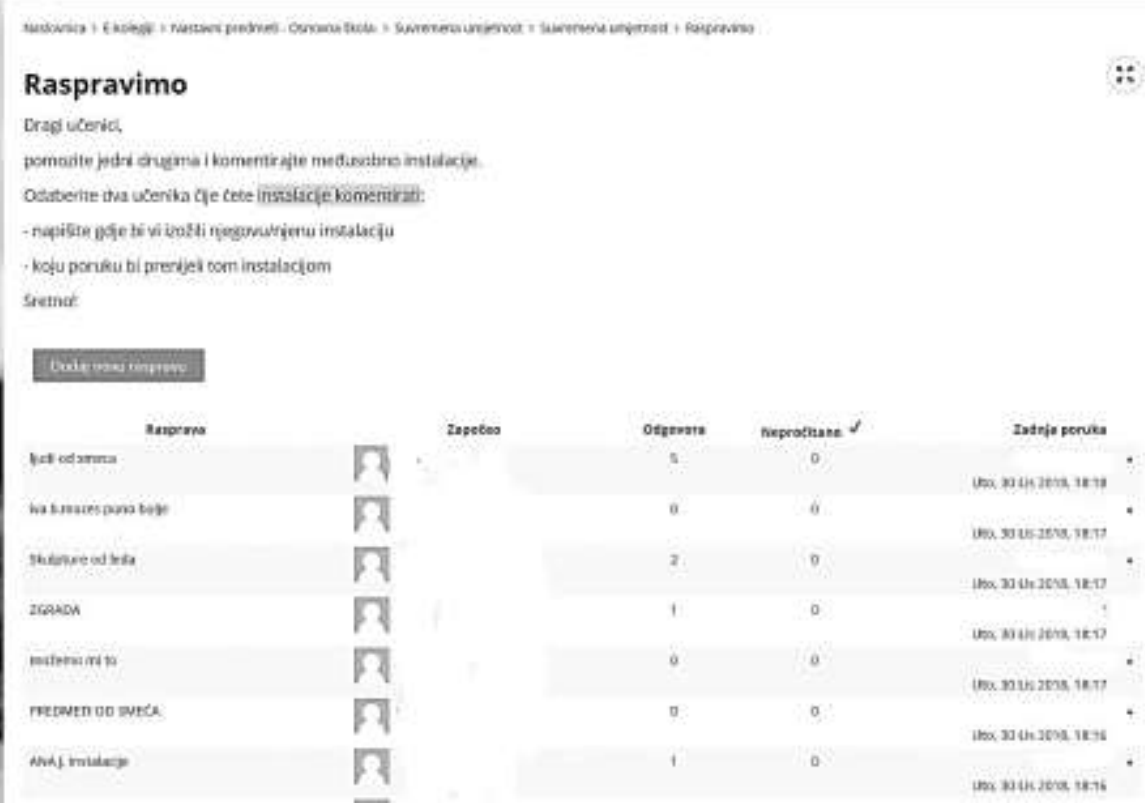

Figure 1. Collaborated and communicated on the Forum in the Moodle

In the third control group $(\mathrm{C})$, students were not taught about contemporary art but observed contemporary works of art.
The research instruments are the following: a visual questionnaire featuring measuring preferences towards contemporary art, objective-type tasks, and the Moodle 
learning satisfaction questionnaire. The visual questionnaire (22 art reproductions) was presented to students in all groups before the education and after the education, i.e., at the beginning of the research and at the end of the research. Students were explained that they would look at pictures belonging to different art periods and made by different authors, whose names we did not mention. We explained to them that they would come to the computer individually, look at the pictures in pairs, decide which one they liked better and then immediately rate each picture on a 5 -interval scale ( $1=\mathrm{I}$ do not like it at all; $2=\mathrm{I}$ do not like it; $3=\mathrm{I}$ somewhat like it; $4=$ I like it; $5=$ I really like it). The evaluation time was fifteen seconds. The pictures shown in pairs were in a rotating order so that the position of the image in the pair would not affect students' judgments. The pair contained one reproduction, belonging to painting and sculptural movements up to the mid20th century, while the other reproduction presented a work of contemporary art. A visual questionnaire with preferences was used at the beginning and the end of the research. Objective-type tasks (ZOT) examined the acquisition of teaching content on contemporary art after the education. The ZOT included the pictures of art installations and interventions that students had already seen and learned about during the lesson (Figure 2).

\section{Moodle}
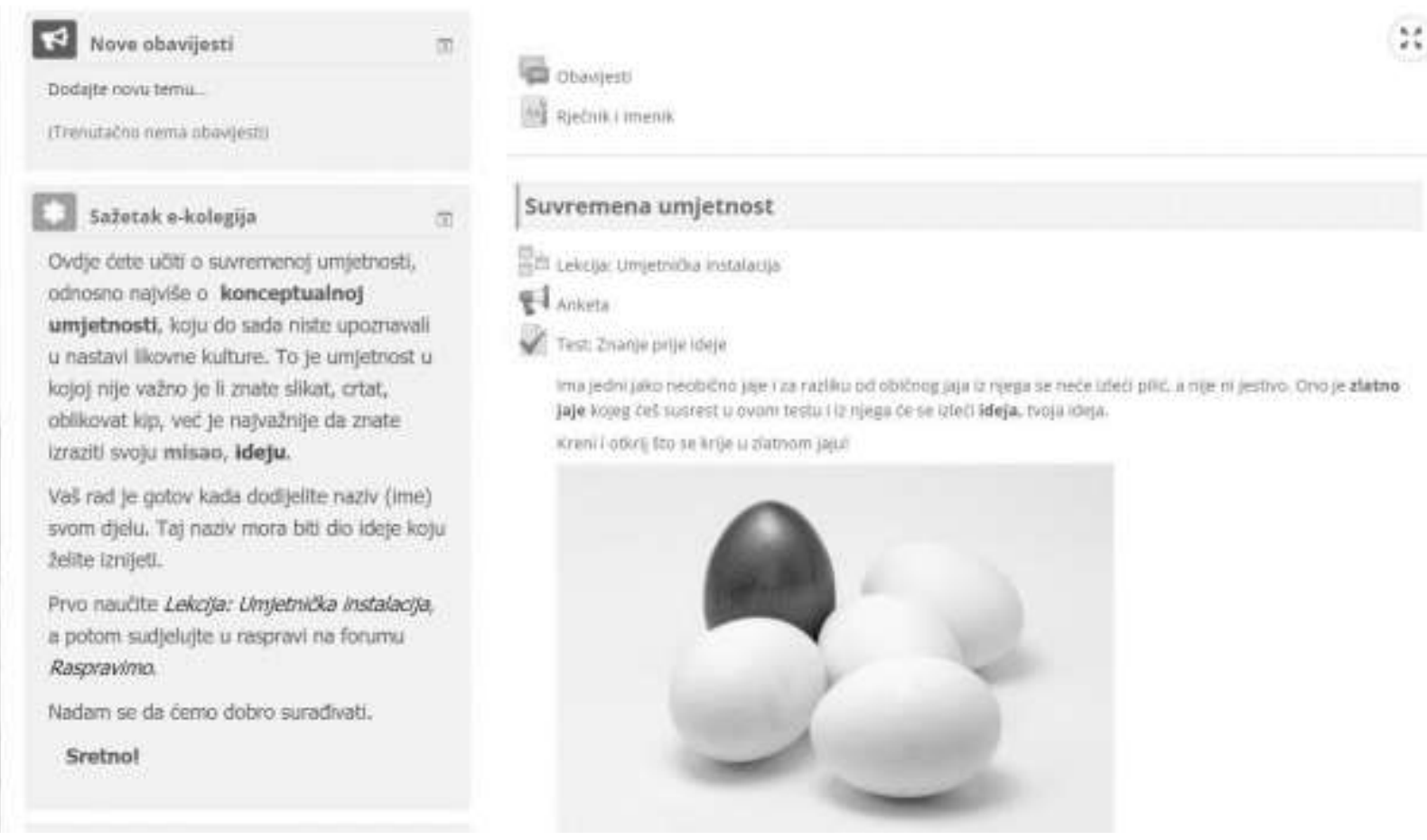

Figure 2. Lesson, test and workshop in the Moodle

The satisfaction questionnaire was designed in Moodle to examine students' satisfaction with Moodle teaching.

\section{Results and discussion}

The first research question: Is there a connection between the way of teaching and the preferences of fourth graders towards contemporary art? aimed at determining which type of art education better influences student preferences towards contemporary art. 
Table 2. Students' preferences regarding contemporary art obtained using visual questionnaire in terms of the education type

\begin{tabular}{|c|c|c|c|c|c|c|c|c|c|c|}
\hline Sample & $\mathrm{M}$ & SD & $\mathrm{N}$ & Dif. & $\begin{array}{l}\text { SD } \\
\text { Diff. }\end{array}$ & $\mathrm{t}$ & $\mathrm{df}$ & $\mathrm{p}$ & $\begin{array}{l}\text { Confi- } \\
\text { dence } \\
-95 \%\end{array}$ & $\begin{array}{l}\text { Confi- } \\
\text { dence } \\
+95 \%\end{array}$ \\
\hline $\begin{array}{l}\text { Group C (con- } \\
\text { trol) }\end{array}$ & 40,63 & 8,74 & & & & & & & & \\
\hline $\begin{array}{l}\text { Group B } \\
\text { (experimental - } \\
\text { Moodle) }\end{array}$ & 45,95 & 5,79 & 19 & $-5,31$ & 10,71 & 2,16 & 18 & 0,04 & $-10,48$ & $-0,15$ \\
\hline $\begin{array}{l}\text { Group C (con- } \\
\text { trol) }\end{array}$ & 40,63 & 8,74 & & & & & & & & \\
\hline $\begin{array}{l}\text { Group A (ex- } \\
\text { perimental - } \\
\text { students creat- } \\
\text { ing on the trail } \\
\text { of contempo- } \\
\text { rary art) }\end{array}$ & 45,00 & 8,15 & 19 & 13,52 & 13,52 & 1,40 & 18 & 0,04 & $-10,89$ & $-2,15$ \\
\hline
\end{tabular}

The difference between the results of the first and second measurements obtained using visual questionnaire with preferences indicates a statistically significant difference between group $\mathrm{C}$ and group $\mathrm{B}$. With a significance level of 0.05 at the degree of freedom 18 the significance level is 2.10 and the significance level we obtained is 2.16. Since after the measurement, the significance obtained was higher than the limit value $(2.16>2.10)$, we conclude that group $B$ has more prominent preferences towards contemporary art after the education (Table 2). There is no statistically significant difference in the preferences towards contemporary art between group $\mathrm{C}$ and group $\mathrm{A}$. Although we can conclude from the results of the arithmetic mean (M 45.00> M 40.63) that students in group $\mathrm{C}$, in which art learning and art creation were omitted, show a decline in preferences in relation to groups in which these were not omitted. As there was no representational education in group $C$, group $C$ in the second measurement using the visual questionnaire showed significantly fewer preferences compared to the other two groups. Tickle, L. /18/ emphasizes the importance of teaching when encountering an artwork and points out that the basic questions are first asked, whereupon in addition to encouraging student interpretation it is important to encourage readiness to accept the unknown. Such an organization of teaching requires special teacher engagement and knowledge that is necessary when encountering conceptual art.

Therefore, we can conclude that education of any kind increases students' preferences towards contemporary art. In order for a teacher to be able to teach students about contemporary art, she/he must know the nature and idea of creating contemporary art. Only an educated teacher can bring contemporary art closer to students and explain it, otherwise she/he contributes to increasing the social gap towards contemporary art.

The obtained results are in contrast to the results of Acer D. and Omeroðlu E. /19/ who also used two experimental groups for research, one of which had a real aesthetic education (a program focused on artworks) and the other a false one (a program focused on judgment) along with one control group in which no training was conducted. The results of the research showed an increase in the aesthetic assessment of children in the group that had quality aesthetic education, yet this increase was not statistically significant compared to the control group.

Asking the second research question, we wanted to check the following: Are fourth graders satisfied with learning using the Moodle system? 
Students of experimental group $\mathrm{B}(\mathrm{N}=19)$ were asked to express their satisfaction with learning about contemporary art using the Moodle system. As a reaction to the statement "I like learning about visual arts using Moodle", $100 \%$ of students said they like learning using Moodle and gave the following grades: very good $(\mathrm{N}=$ $4)$ and excellent $(\mathrm{N}=15)$. They were most satisfied (58 \%) with communicating and collaborating using communication and collaboration tools (forum and chat). The results were expected because today's students, digital natives, like to use the Internet $(21 \%)$ and are accustomed to social networks /op.cit. 13/. Based on students' desire for communication, their task was to design and describe the installations using the forum. They gladly participated in the forum, which is confirmed by the fact that they opened over 30 discussions on the forum featuring the task. It is important to note that the teacher who encouraged the culture of behavioral communication also participated in all discussions. The task forum, as a tool to solve problems by communicating with others, was chosen based on other researches that confirm students' interest in communication. Over $60 \%$ of primary school students often use some of social network tools, which is why we assumed that students would be happy to participate in task elaborations using discussion $/ \mathbf{2 0}$. Our results ( $58 \%$ ) confirm the results of the research conducted by Ivanković /op.cit. 20/, in which $68 \%$ of students answered that it would be desirable to use social network tools for learning and communication between students and teachers.

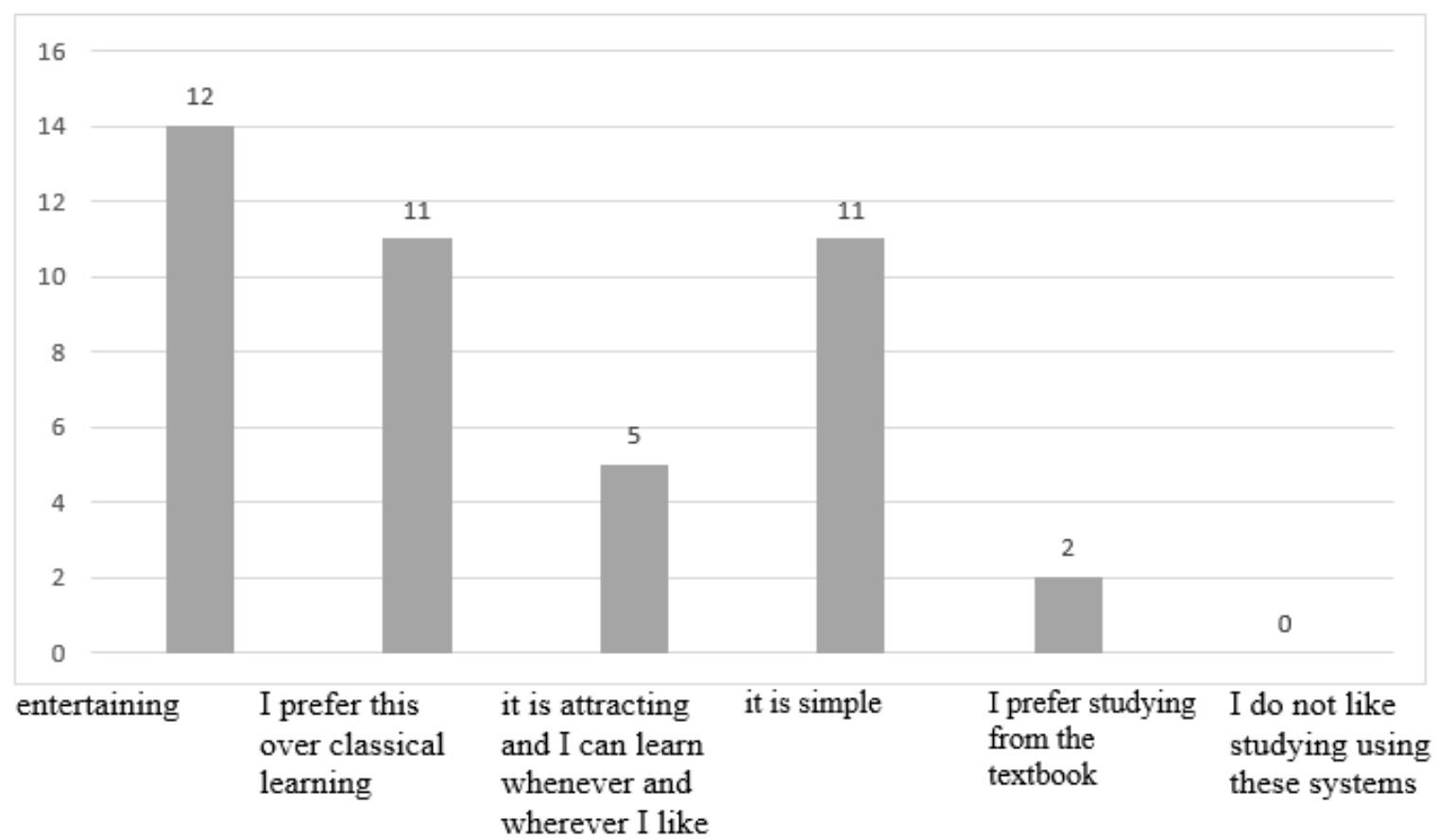

Graph 1. Students' satisfaction with the Moodle system

Graph 1 shows students' satisfaction with the Moodle system in relation to previous, classical learning in the classroom environment. Students were able to select multiple answers. The contents were presented to the students with text, image, video, animation, materials that provide various opportunities for educational work. The reason why students characterized
Moodle as entertaining ( $F=12)$ is the teaching content in which audio and video tools and communication tools (chat, forum) were used, which the students really liked. In the research conducted by Ivanković /op.cit. 20/, $80 \%$ of students answered that they should use more multimedia digital materials in teaching, therefore it was expected that students would like 
our designed teaching materials, consider them entertaining, and prefer to use them over textbooks and classical teaching. The obtained results on the description of the system and digital content are also in accordance with the survey by Ivanković /op.cit. 20/ in which $76 \%$ of students described digital content as entertaining, which was confirmed by our research in which most students ( $\mathrm{F}=12,35 \%)$ described learning on Moodle as entertaining.

With the third research question, we wanted to find out the following: Is there a difference in knowledge about contemporary art between students of group $A$ and group $B$ in terms of the difference between initial and final measurement in objective-type tasks (ZOT)?

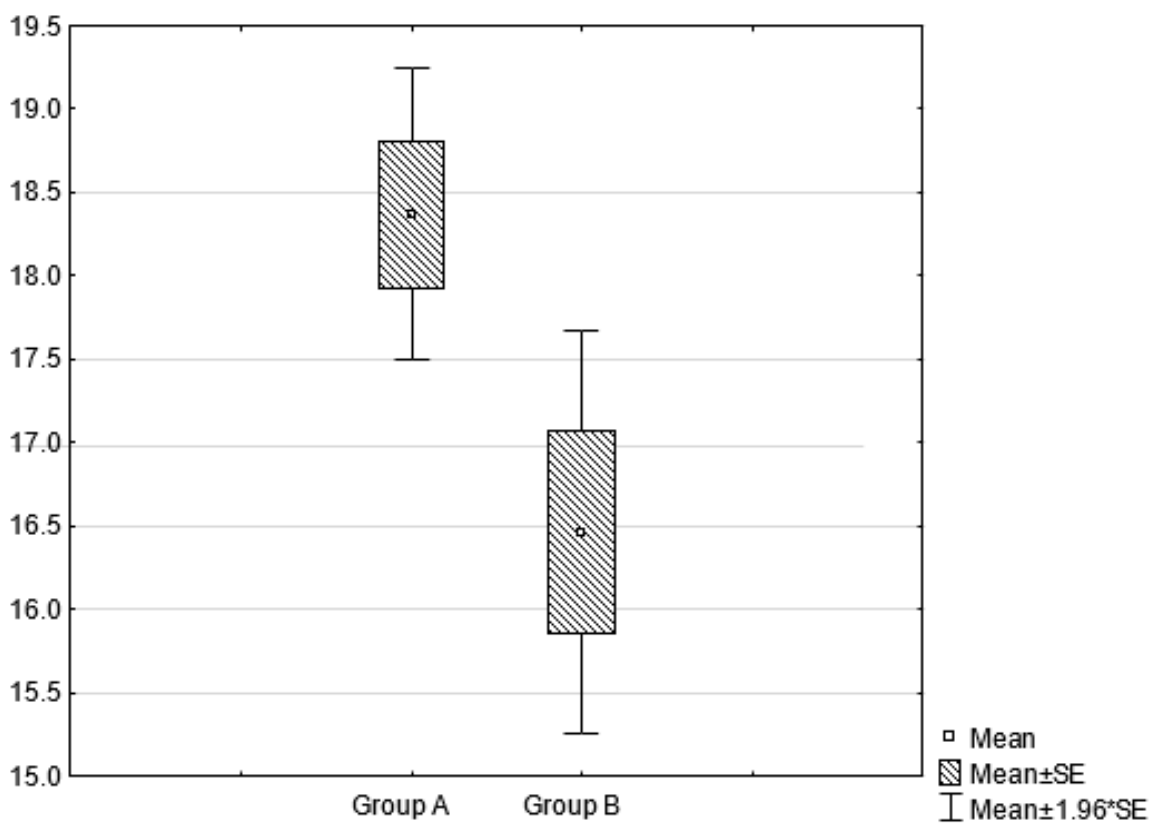

Graph 2. The results of the difference between initial and final measurement test (ZOT) of the group B (teaching on Moodle) and the group A (students creating on the trail of contemporary art)

Using the T-test (Table 3) we checked the differences between the initial and final test (ZOT) of the group taught on the Moodle system (B) and the group (A) in which students created artworks on the trail of contemporary art. At a significance level of 0.05 and degrees of freedom (df) 36, the cut-off value is 2.04. Given that the value of the t-test in this study is 2.50 , we can conclude that there is a statistically significant difference $(t(N 19)=2.50, p<0.05)$. The difference that occurred was in favor of group A (MA 18, 37> MB 16.46), i.e. students who created on the trail of contemporary art. It can also be seen from Graph 2 that group B had a significantly higher dispersion of results compared to group A.

Table 3. The results of the difference between initial and final measurement test (ZOT) of the group B (teaching on Moodle) and the group A (students creating on the trail of contemporary art)

\begin{tabular}{|l|l|l|l|l|l|l|l|l|l|l|l|}
\hline Group & $M A$ & $M B$ & $t$ & $d f$ & $p$ & $N A$ & $N B$ & $S D A$ & $S D B$ & $F$ & $P$ \\
\hline A and B & 18,37 & 16,46 & 2,50 & 36 & 0,08 & 19 & 19 & 1,95 & 2,69 & 1,90 & 0,18 \\
& & & & & & & & & & & \\
\hline
\end{tabular}


As we found no similar research, we compared our data with groups whose field knowledge and age did not correspond to our group. The author $/ \mathbf{2 1} /$ examined the field of biology. The test was intended for fifth, sixth, seventh and eighth grade students, it tested the knowledge of students taught on Moodle and students taught in a classical classroom environment. The obtained results showed that there was no statistically significant difference in the arithmetic means of the final test results between the two groups. Other researchers conducted at a university level, which examined the impact of the Moodle system on teaching in relation to classical teaching, showed that students did not have statistically significant achievements in e-learning compared to the group educated in traditional teaching /22/. Learning using the Moodle system contributes to improving student learning, teaching, and knowledge testing. Their attention is focused on the teaching content using different colors, images, web links, and interesting examples, making learning really effective. This results in very successful test achievements /23/. Students who created on the trail of contemporary art did the test better because they worked in a typical atmosphere and environment, that is, more common for them to learn and work. Numerous studies show that the most stimulating environment for student development is precisely the one that provides emotional and cognitive support to students and the one that offers meaningful and clear content that students will be able to use /24/. We do not have to look for the reason in the contents, as both examined groups of students showed understanding and satisfaction with the designed contents. Due to the lack of e-learning practice in the lower grades of primary school, students find it more difficult to perceive e-learning as "real" teaching and have not developed sufficient responsibility for fully independent learning of new content using Moodle.

\section{Conclusion}

In this paper, we wanted to analyze the application of modern technologies in education. In the described educational experiment, we chose to teach students about contemporary art within the framework of Visual arts lessons helping students to be included in the society and time in which they live. We introduced students to contemporary art using Moodle. From the above results, we can conclude that additional art education has influenced students' preferences towards contemporary art. We found that students find this teaching method entertaining and useful, and that they are satisfied with such lessons.

The research confirmed students' interests in multimedia content, as well as in communication and collaboration, which should certainly be considered in the next research. The research was not conducted on a large number of students because several components were included in the research, making the research very complex. The research included the design of teaching content in the e-learning system, the design of a visual questionnaire, the artistic creation of students on the trail of contemporary art. It is recommended that the next study of the same character identify the difference between students of different ages and both sexes.

Any new research based on the determinants of this research contributes to the overall assessment of the Moodle system and the importance of contemporary art in teaching.

Our recommendation for teachers who want to introduce students to contemporary art is to use teaching content designed on Moodle, if there are technical possibilities, saving time and achieving creative expression in teaching.

Notes

/1/ Karlavaris, B. (1991). Metodika likovnog odgoja 2. Rijeka: Hofbauer.

/2/ Šuvaković, M. (1999). Pojmovnik moderne i postmoderne likovne umjetnosti $i$ teorije posle 1950. godine, Beograd-Novi Sad: Srpska akademija nauka i umjetnosti Prometej.

/3/ Vrlič, T. (2001). Suvremena umjetnost u likovnom odgoju u osnovnoj školi. In: R. Ivančević, \& V. Turković (eds.) Vizualna kultura i likovno obrazovanje (pp. 117-131). Zagreb: Hrvatsko vijeće međunarodnog društva za obrazovanje putem umjetnosti.

/4/ Karlavaris, B. (1991). Metodika likovnog odgoja 2. Rijeka: Hofbauer.

/5/ Baranović, B. (2006). Nacionalni kurikulum za obvezno obrazovanje u hrvatskoj - različite perspektive. 
Zagreb: Institut za društvena istraživanja u Zagrebu Centar za istraživanje i razvoj obrazovanja, pp. 8-37.

/6/ Cole I. (1996). Young People and Contemporary Art. v Dawtrey Liz (Et. al). (eds.). Critical Studies and Modern Art. New Haven and London: Yale University Press, pp. 145-151.

/7/ Duh, M. \& Župančič, T. (2009). The communicative possibilities of contemporary art within the frame of art education. Informatologia, 42 (3), 180$185 . \quad$ Downloaded from: https://hrcak.srce.hr/41111

/8/ Herzog, J. \& Duh, M. (2013). Examples of Applying Contemporary Art Practices in the Visual Arts Curriculum in Grammar Schools. Croatian Journal of Education, 15 (Sp. Ed. 1), 55-69. Downloaded from: https://hrcak.srce.hr/106513Ž.

/9/ Tomaš, S. \& Gović, L. (2019). Samoprocjena digitalnih kompetencija studenata. In: Dumančić, M. \& Pavlin Homen, M. (eds.) Uloga i mogućnosti informacijske i komunikacijske tehnologije (IKT) u predškolskom i osnovnoškolskom obrazovanju te obrazovanju učitelja. Zagreb, Sveučilište u Zagrebu, Uciteljski fakultet, pp. 27-42.

/10/ Nenadić A., Krajnović A. \& Jašić D. (2012). Prikaz modela implementacije LMS - Moodle (Learning Management System) sustava u visokom obrazovanju pomoraca, Oeconomica Jadertina, (2) 1, pp. 59-71.

/11/ Hutinski, Ž. \& Aurer, B. (2009). Informacijska i komunikacijska tehnologija u obrazovanju: stanje i perspektive. Informatologia, $42(4), \quad$ 265-272. Downloaded from: https://hrcak.srce.hr/42347

/12/ Prensky, M. (2010). Teaching digital natives: Partnering for real learning. Corwin press, 2010.

/13/ Kerr, B. (2012). Design preferences for and attitudes concerning e-learning in a global organization (Doctoral dissertation, Concordia University).

/14/ Siemens, G. (2004). Connectivism: a learning theory for the digital age (2004). http://www. elearnspace. org/Articles/connectivism. htm (June 12, 2019).
/15/ Moodle (2014.) Pedagogy. Available at: http://docs.moodle.org/27/en/Pedagogy (June 1, 2014)

/16/ Tomaš, S. (2015). Vrednovanje sustava e-učenja za učenike osnovnoga obrazovanja, Doctoral dissertation, Filozofski fakultet, Zagreb.

/17/ Khoroshko, L. L., Vikulin, M. A., Kvashnin, V. M. \& Kostykova, O. S. (2019). Communication with Students in Smart e-Learning System Using LMS Moodle. Smart Education and e-Learning, Springer, Singapore, 177-185.

/18/ Tickle, L. (Ed.) (1996) Understanding Art in Primary Schools: cases from teachers' research. London: Routledge.

/19/ Acer, D., \& Ömeroðlu, E. (2008). A study on the effect of aesthetic education on the development of aesthetic judgment of six-year-old children. Early Childhood Education Journal, 35(4), 335342. https://doi.org/10.1007/s10643-007-0193-4

/20/ Ivanković, R. (2013), Primjena e-učenja u nastavi. Available at: http://prezi.com/usn9xfbjn4q/primjena-e-ucenja-u-nastavi/ (May 25, 2019)

/21/ Bulić, M. (2018). Biology achievement of learning outcomes in e-learning. Educatio biologiae, (4.), 6768. https://doi.org/10.32633/eb.4.7

/22/ Tokić, I. (2012). Pristup oblikovanju eksperimenta za vrednovanje sustava e-učenja. Available at: http://www.pmfst.hr/ ani/radovi/diplomski/Tokic_Ivana_2012.pdf (June 12, 2014).

/23/ Kuščević, D., Tomaš, S. \& Mornar, I. (2016). Primjena sustava Moodle $\mathrm{u}$ metodici nastave likovne kulture. Zbornik radova Filozofskog fakulteta $u$ Splitu, (6-7), 86-102. Downloaded from: https://hrcak.srce.hr/154579

/24/ Eccles, J. \& Roeser, R. (2009). Scfools, Academic Motivation, and Stage-Environment Fit. In: R. M. Lerner and L. Stenberg (Eds.) Handbook of adolescent psychology (404-434). Hoboken, N.J.: John Wiley. 